\title{
Recovery of Schistosoma japonicum from Experimentally Infected Pigs by Perfusion of Liver and Mesenteric Veins
}

\author{
By H. O. Bøgh ${ }^{1}$, A. Lee Willingham III I,2, M. V. Johansen ${ }^{2}$ L. Eriksen ${ }^{3}$ and N. Ø. Christensen ${ }^{2}$ \\ ${ }^{1}$ Danish Centre for Experimental Parasitology, and ${ }^{3}$ Department of Clinical Studies, The Royal Veterinary and \\ Agricultural University, Frederiksberg, and ${ }^{2}$ Danish Bilharziasis Laboratory, Charlottenlund, Denmark.
}

\begin{abstract}
Bøgh, H.O., A. L. Willingham III, M.V. Johansen, L. Eriksen and N. Ø. Christensen: Recovery of Schistosoma japonicum from esperimentally infected pigs by perfusion of liver and mesenteric veins. Acta vet. scand. 1997, 38, 147-156. - An optimized procedure for perfusion of pigs infected with Schistosoma japonicum was developed. The technique involves insertion of a perfusion influx tube into the thoracic descending aorta, clamping vessels to parts of the body which did not need to be perfused (the kidneys, hind legs, etc.) and placing a collection tube directly into the portal vein. In addition, the clamping technique allows for separate perfusion of the liver and intestinal veins. The perfusion medium was a sodium citrate buffer $\left(40^{\circ} \mathrm{C}\right)$ to which the vasodilator sodium nitroprusside was added. Furthermore, an experiment was conducted to investigate if the perfusion efficiency, measured by total worm recovery, could be increased if praziquantel was administered prior to perfusion. Twelve pigs were each infected with $1000 \mathrm{~S}$. japonicum cercariae and their schistosomes were collected 11 weeks later by separate perfusion of the liver and intestinal veins. Six of these pigs were treated orally with praziquantel one hour before perfusion. In general, the vessels of the livers and intestines of all pigs were well perfused, judging by the resulting pale colour of the tissues. Worms from praziquantel treated pigs were collected within $5 \mathrm{~min}$ of perfusion as opposed to approximately $20 \mathrm{~min}$ in the non-treated pigs. More worms were collected from the livers of the praziquantel treated pigs, indicating a hepatic shift of schistosomes from the intestinal mesenteries. However, comparable numbers of worms were retained in the mesenteric veins following perfusion in the 2 groups, indicating that manual recovery of schistosomes from the intestinal mesenteries is necessary in addition to perfusion for obtaining the total worm counts. Another experiment was conducted to determine if the intensity and/or duration of infection had an effect on the number of worms collected by the perfusion technique. Seventy-two pigs were allocated into 3 groups of 24 pigs each, which were infected with either 100,500 or 2000 cercariae per pig. The 3 groups were further divided into 4 subgroups of 6 pigs each which were perfused with our selective technique at $4,11,17$ or 24 weeks post infection, respectively. All of the pigs received an oral praziquantel treatment prior to perfusion. The results indicated that increasing intensities and/or duration of infection resulted in trapping of schistosomes in intravascular inflammatory reactions which made it more difficult to collect the adult schistosomes by perfusion.
\end{abstract}

trematoda; praziquantel. 


\section{Introduction}

The zoonotic blood fluke Schistosoma japonicum is endemic in parts of China, the Philippines and Indonesia, where a large range of mammals, including humans, cattle, water buffaloes, pigs, dogs and rodents, serve as definitive hosts (Kumar \& Burbure 1986, Chen 1993). The adult schistosomes inhabit the mesenteric veins of the intestines. Therefore, in order to determine the intensity of infection it is usually necessary to flush the worms from these vessels by perfusion of the host's hepatic portal system. Standard, easily performed procedures exist for perfusion of laboratory rodents (Smithers \& Terry 1965, Duvall \& DeWitt 1967, James \& Taylor 1976, Moloney \& Webbe 1982), however perfusion of large animals such as monkeys (Smithers \& Terry 1965, Damian et al. 1986, Wilson et al. 1990), cattle (Bushara et al. 1983), pigs (Yason \& Novilla 1984, Willingham et al. 1996) and goats (Johansen et al. 1996) remains a time consuming and laborious process. The domestic pig, an important natural host of $S$. japonicum, has recently been proposed as a unique host model for schistosomosis japonica (Willingham et al. 1994, Willingham \& Hurst 1996). Early experiments involving $S$. japonicum infected pigs have shown that standard perfusion techniques are not capable of fully flushing the extensive splanchnic vasculature of the pig (Bøgh et al. unpublished), thus a more selective perfusion method of the porcine hepatic portal system is required. Furthermore, in contrast to schistosomes in laboratory rodents which readily shift to the liver following barbiturate euthanasia of the host (Smithers \& Terry 1965), many worms have remained, in the pigs' mesenteric veins subsequent to perfusion in spite of barbiturate euthanasia. This has resulted in lengthy examination of the mesenteric vessels post perfusion to locate residual schistosomes. Optimization of the perfusion procedure for pigs is therefore warranted in order to develop a more rapid, effective and reliable method for collection of $S$. japonicum worms so that the model can be utilized in future population dynamic studies.

The aim of the present study was to develop a technique which would selectively perfuse the hepatic portal system of pigs by preventing the flow of perfusion fluid to nonpertinent areas of the body (i.e. cranial body, kidneys, hind legs, etc.) and thereby increase the fluid pressure in the hepatic and intestinal vasculature resulting in more effective flushing of these organs. In addition, we also investigated the use of oral praziquantel as a pre-perfusion treatment of pigs to reduce the number of residual worms in the mesenteric vessels following perfusion. The decision to use praziquantel was based on studies which have shown that the drug paralyzes schistosomes within minutes following oral treatment of host animals, causing the worms to losen their attachment to the inner lining of the intestinal veins and passively shift to the liver (Gönnert \& Andrews 1977, Andrews 1985). We also tested the combination of selective perfusion and pre-perfusion praziquantel treatment in pigs with varying intensities and durations of infection.

\section{Materials and methods}

Experimental animals and parasite material Specific pathogen-free (MS-SPF) Danish Landrace/Yorkshire/Duroc crossbred pigs, initially 6-10 weeks old, were used for the experiments. They were housed together randomly under helminth-free conditions and fed a standard ration of ground barley and protein supplement with water provided ad libitum. The pigs were infected with an isolate of $S$. japonicum originating from Anhui Province, People's Republic of China (Willingham et al. 1994). The isolate is maintained in Oncomelania hupensis hupensis at the Danish Bilharziasis La- 
pensis hupensis at the Danish Bilharziasis Laboratory. Cercariae were administered by intramuscular injection according to the method described by Willingham et al. (1996).

\section{Experimental design}

Two experiments were conducted. In the first experiment 12 castrated male pigs were each infected with 1000 cercariae and then killed 11 weeks post infection (p.i.). They were randomly assigned to 2 groups: Group $1(n=6)$ was treated with praziquantel (Bayer, Leverkusen, Germany) prior to perfusion while Group 2 ( $\mathrm{n}=$ 6 ) was not. Treated pigs were given a solution of praziquantel $(50 \mathrm{mg} / \mathrm{kg})$ dissolved in propylene glycol $(5 \mathrm{~g} / \mathrm{l})$ which was administered by stomach tube one hour prior to perfusion. The pigs were perfused in random order, alternating between the 2 groups. Worm recoveries of the 2 groups were compared on the basis of the site from where the worms were collected by perfusion (liver vs. intestines) and the number of residual worms recovered from the intestinal vessels post-perfusion. Plain propylene glycol was not given to Group 2 pigs, because it was shown in a separate experiment (Bøgh, unpublished) that propylene glycol itself does not affect perfusion of pigs infected with $S$. japonicum. This is in agreement with studies on $S$. bovis in goats (Johansen 1994).

In a second experiment 72 pigs, 36 castrated males and 36 females, were allocated according to sex, weight and litter origin into 3 groups of 24 pigs. The groups were infected with either 100,500 or 2000 cercariae per pig. These 3 groups were further divided into 4 subgroups of 6 pigs each, also based on sex, weight and litter origin. One subgroup from each group was euthanatized and perfused with our selective technique at $4,11,17$ and 24 weeks p.i., respectively. All of the pigs received oral praziquantel treatment prior to perfusion according to the procedure described above. The number of re- sidual worms (as a percentage of the total worms recovered) following perfusion of these different subgroups were compared to determine if intensity and/or duration of infection had an effect on the number of worms collected by our perfusion technique.

\section{Perfusion procedure}

Pigs were sedated in their box with an i.m. injection of azaperonum (Janssen, Belgium; 8 $\mathrm{mg} / \mathrm{kg}$ body weight) approximately $30 \mathrm{~min}$ before perfusion. Just prior to perfusion an indwelling intravenous catheter (Venaject, Ohmeda, Helsingborg, Sweden) was placed in an auricular vein of the sedated pig and heparin (500 IU/ $/ \mathrm{kg}$ ) administered followed by pentobarbital (5-10 mg/kg body weight) to anesthetize the pigs for transport to the perfusion room where they were euthanized with i.v. pentobarbital ( $30 \mathrm{mg} / \mathrm{kg}$ body weight) immediately before perfusion. Following euthanasia, the thorax and abdomen of the pigs were opened by means of a full-length ventral midline incision. In order to selectively perfuse the hepatic portal system, clamps were placed on the following vessels: 1) the thoracic caudal vena cava near the diaphragm; 2) the right renal artery and vein; 3) the right and left common iliac arteries just caudal to the bifurcation of the abdominal aorta (these were found easily by locating the iliac lymph nodes); 4) the abdominal aorta just caudal to the left renal artery and cranial mesenteric artery; and 5) the left renal artery and vein. Clamping of these vessels prevented the perfusion of the kidneys, the rear legs and other unnecessary areas. Furthermore, it prevented the schistosomes to leave the liver. A conscious effort was made to disturb the intestines as little as possible when placing these clamps in order not to hamper the eventual flow of perfusion fluid through the mesenteric vessels. After placing the clamps, a $1 \mathrm{~cm}$ scalpel incision was made in the thoracic descending aorta as crani- 
ally as possible, and a rubber perfusion influx tube with a diameter of $0.6 \mathrm{~cm}$ was inserted in a caudal direction approximately $10 \mathrm{~cm}$ so that the end of the tube was just proximal to the celiac artery. The influx tube was fixed by a ligature. Afterwards a clamp was placed on both the aorta and azygous vein just cranial to the tube insertion site.

After insertion of the influx tube in the aorta, the portal vein was located in the hepato-duodenal ligament. A clamp was placed on the vein as proximally as possible at its entrance into the liver and an additional clamp placed at the distal visible end resulting in a $6-10 \mathrm{~cm}$ section of the vein between the 2 clamps. A $14 \mathrm{G}$ needle attached to a $20 \mathrm{ml}$ syringe was used to puncture the vein in the center of the clamped area and the blood in this section of the portal vein removed with the syringe. This blood was immediately examined for schistosomes. A scalpel was then used to make a $1 \mathrm{~cm}$ incision in the portal vein using the puncture hole for guidance. An L-shaped, hard plastic tube was then inserted into the portal vein with the opening cranially toward the liver and secured with a ligature. A $1 \mathrm{~m}$ long rubber hose was attached to the tube and directed to a $39 \mu \mathrm{m}$ or $45 \mu \mathrm{m}$ collection sieve.

For perfusion of the liver the proximal portal vein clamp was removed and the perfusion fluid pumped. The perfusate passed out through the hose and into the sieve where any schistosomes were caught. After perfusion of the liver the perfusion pump was turned off and the clamp reapplied to the portal vein.

The ligature was cut and the L-tube removed. It was then turned around and replaced into the portal vein in a caudal direction toward the intestines. Again a ligature was placed around the vein to secure the tube, the distal clamp removed and the pump turned on to perfuse the vessels of the intestine. Clamp number 4 listed above was placed on the abdominal aorta so that most of the perfusion fluid would be directed into the cranial mesenteric artery at the beginning of the intestinal perfusion in order to have enough pressure to flush the mesenteric vessels of the small intestine, caecum and colon. This clamp was removed toward the end of perfusion in order to send perfusion fluid into the caudal mesenteric artery so that the rectum could also be fully perfused.

The perfusion fluid was made by dissolving $150 \mathrm{~g}$ sodium citrate and $85 \mathrm{~g} \mathrm{NaCl}$ (Smithers \& Terry 1965) per $10140^{\circ} \mathrm{C}$ tap water and adding $10 \mathrm{ml}$ of a solution of the vasodilator sodium nitroprusside ( $450 \mathrm{mg}$ dissolved in 11 isotonic glucose). The fluid was pumped at a flow rate of $1.8 \mathrm{1} / \mathrm{min}$ (Easy-Load, MasterFlex Model 7518-00, Cole Parmer Instrument, Chicago, USA). Perfusion of the liver was accomplished using $51 / 100 \mathrm{~kg}$ bodyweight and the intestines were perfused using $25 \mathrm{l} / 100 \mathrm{~kg}$. Separate sieves were used to collect the schistosomes from the 2 locations. During the perfusion, the intestines were covered with a warm, moist towel to help facilitate with their perfusion by keeping the intestinal vessels dilated. Perfusate which seeped out around the collection tube was suctioned with a vacuum hose into a 10 or 201 glass flask and later poured through the sieve to collect any schistosomes. Vacuumed perfusate from the liver was sieved seperately from that of the intestines.

After perfusion the entire intestinal tract of each pig was removed and the mesenteric vessels thoroughly examined for the presence of residual worms. The mesenteries of the colon were clipped in order to uncoil this part of the pig's large intestine. The entire large intestine was then stretched out on a necropsy table in order to enable the examination. The small intestine and its mesenteries were inspected separately.

The schistosomes collected were placed in 100 $\mathrm{ml}$ plastic cautex bottles containing $70 \%$ alco- 
hol, with worms from each pig and from each organ put into separate containers. A stereo microscope was used to enumerate the worms and classify them according to sex and maturity. Schistosomes were classified as adults or immature worms based on their morphology.

\section{Statistical analyses}

Data from the first experiment were analysed by performing Student's t-tests and MantelHaenszel $2 \times 2$ tables to examine possible differences between the praziquantel-treated and non treated pigs.

\section{Results}

The selective technique greatly facilitated perfusion of the pig's portal system as evidenced by livers and intestines of all pigs in both experiments being well perfused. In some cases difficulty was encountered with full perfusion of the jejunum, however, manual inspection of this section of the intestine post-perfusion did not reveal the presence of schistosomes. In general, it took about 15-20 min to open the pig's thorax and abdomen, place the clamps on the specified vessels, insert the influx tube into the aorta and place the collection tube into the portal vein, before actually being able to start the perfusion. By securing the L-tube in the portal vein with ligatures we were able to greatly reduce seepage of perfusate around the tube thereby keeping use of the vacuum pump to a minimum. It was also discovered that if the Ltube was held in the proper position in the portal vein one could actually elicit a "pumping action" by the pig's vasculature when the tube was placed both toward the liver and intestines. Once this "pumping" occurred, these organs perfused extremely quickly as evidenced by their rapid change in colour.

In the first experiment, pigs harboured between 44 and 158 worms, with a mean \pm sd of $87 \pm 35$.
Immature worms constituted $36 \%$ of the total number of worms. The male: female ratio of the total number of adult worms was 0.8 , and there were no significant differences between the numbers of male, female or immature worms in the praziquantel treated and non treated groups. The numbers of worms perfused from the livers and mesenteric vessels and the number recovered following perfusion by examination of the mesenteric vessels for the 2 groups are shown in Table 1. In general, worms were flushed out of the treated pigs very quickly, usually within $5 \mathrm{~min}$, whereas worm collection from untreated pigs, especially from the intestinal veins, was more gradual, usually requiring $15-20 \mathrm{~min}$. Significantly more adult male and female worms were perfused from the livers of pigs previously treated with praziquantel $(\mathrm{p}<0.001$ and $p<0.01$, respectively). However, no significant difference was observed in the number of immature worms perfused from the livers of the treated and untreated groups. In addition, no significant difference was found between the 2 groups with regard to number of worms perfused from intestinal mesenteric veins nor in the mean numbers of residual worms post-perfusion.

The number and percentage of residual adult $S$. japonicum worms recovered at different time points from pigs infected with either 100, 500 or 2000 cercariae are shown in Table 2. At 4 weeks p.i., the percentage of the total number of adult worms remaining following perfusion was $0 \%, 4.7 \%$ and $3.6 \%$ for the low, medium and high dose group, respectively. However, at 24 weeks p.i. these percentages increased to $37 \%, 47.9 \%$ and $94.8 \%$, respectively. At 17 and 24 weeks p.i. many worms, especially in the high dose group, were found trapped in intravascular inflammatory reactions in the mesenteries making their extraction impossible. 


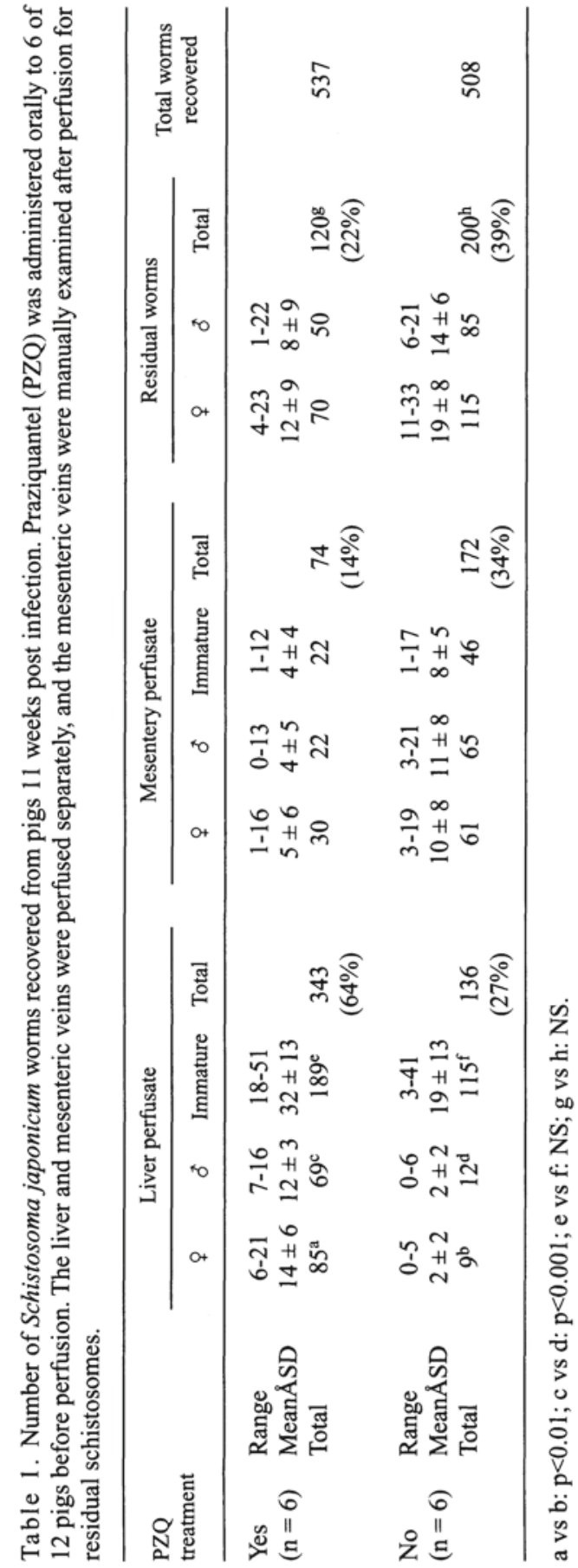

\section{Discussion}

The perfusion of pigs infected with $S$. japonicum was considerably improved, judged by the degree of paleness, by incorporating procedures found helpful in preliminary experiments. These included the use of warm perfusion fluid to which a vasodilator was added, placement of a collection tube directly into the portal vein, and preventing the perfusion of nonessential parts of the circulatory system. This was achieved by clamping vessels to the kidneys and caudal extremities, which greatly aided in directing the perfusion fluid to the hepatic portal system and resulted in very effective flushing of the vessels in that area. Perfusion was further enhanced by the "pumping" of the pigs' splanchnic vasculature which was elicited by correctly positioning the collection tube in the portal vein. This interesting phenomenon enabled the perfusions to be completed very quickly.

Pre-perfusion treatment of pigs with oral praziquantel provided the added benefit of shortened perfusion time due to schistosomes "shifting" from the intestinal mesenteric veins to the liver as seen in the first experiment. Although significantly more worms were perfused from the livers of praziquantel treated pigs, the total numbers of worms perfused from the treated and non treated groups were not significantly different. This indicates that praziquantel did not damage the worms in such a way that they disintegrated or were trapped in the liver during the hour before perfusion. A total of 74 worms were perfused from the mesenteric veins of the praziquantel treated pigs, whereas 172 worms were perfused from the untreated group. This difference, however, was not significant primarily due to a relatively high number of worms in one of the pigs in the praziquantel treated group. Of in total 158 worms, 79 and 41 were perfused from the liver and mesenteric veins, respectively. However, the worms per- 
Table 2. Number and percentage of residual adult Schistosoma japonicum worms recovered from 6 pigs infected with either 100,500 or 2,000 cercariae. The liver and mesenteric veins were perfused separately $4,7,11$ or 24 weeks post infection and the mesenteric veins were manually examined after perfusion for residual schistosomes.

\begin{tabular}{lccc}
\hline Cercarial dose & $\begin{array}{c}\text { Total number of } \\
\text { adult worms }\end{array}$ & $\begin{array}{c}\text { Number of residual } \\
\text { adult worms }\end{array}$ & $\begin{array}{c}\text { Percentage of adult worms } \\
\text { collected manually }\end{array}$ \\
\hline 4 weeks post infection & & & \\
100 & 58 & 0 & 0 \\
500 & 71 & 38 & 4.7 \\
2,000 & 1,069 & & \\
11 weeks post infection & & 26 & 48.6 \\
100 & 54 & 30 & 39.5 \\
500 & 76 & 606 & 79.7 \\
2,000 & 760 & & \\
17 weeks post infection & & 10 & 32.3 \\
100 & 31 & 78 & 67.8 \\
500 & 115 & 594 & \\
2,000 & 653 & & 37.0 \\
24 weeks post infection & & 10 & 47.9 \\
100 & 27 & 34 & 94.8 \\
500 & 71 & 476 & \\
2,000 & 502 & & \\
\hline
\end{tabular}

from the mesenteric veins of this pig were collected within $1 \mathrm{~min}$ after the onset of the perfusion.

We discovered that no matter how well the intestines were perfused, residual schistosomes were almost always still found post-perfusion. However, perfusion of the veins greatly facilitated the search for these residual worms as they were easily located when the organ was pale. It remains to be determined whether a longer interval between praziquantel administration and perfusion would result in a greater number of perfused worms or, on the other hand, result in tegumental damage to the schistosomes thereby hampering their collection.

Results from the second experiment indicate that with increasing intensities and/or duration of infection, the number of schistosomes that can be recovered by perfusion decreases, probably due to increasing host reactions which immobilize the worms.
In summary, collection of $S$. japonicum worms from pigs was facilitated by selective perfusion of the hepatic portal system. Furthermore, the perfusion time was reduced by pre-perfusion treatment of pigs with oral praziquantel. However, following perfusion some worms were still found in the mesenteric veins and their numbers were related to increasing intensity and duration of infection. Thus, even with this optimized perfusion procedure, the mesenteric veins will still need to be examined for residual $S$. japonicum worms when enumeration of the total worm burden is required.

\section{Acknowledgements}

The Danish National Research Foundation is thanked for providing financial support. A. Mehlsen and N.P.K. Hansen are thanked for excellent technical assistance. Sjælland III Swine Research Station is kindly acknowledged for good animal care. The pigs used in this experiment were treated in accordance with animal ethics laws of Denmark. 


\section{References}

Andrews P: Praziquantel: mechanisms of antischistosomal activity. Pharmacology and Therapeutics, 1985, 29, 129-156.

Bushara HO, Hussein MF, Majid MA, Musa BEH, Taylor $M G$ : Observations on cattle schistosomiasis in the Sudan, a study in comparative medicine. IV. Preliminary observations on the mechanisms of naturally acquired resistance. Am. J. Trop. Med. Hyg. 1983, 32, 1065-1070.

Chen MG: Schistosoma japonicum and S. japonicum-like infections: Epidemiology, clinical and pathological aspects. In: Jordan, P, Webbe, G, Sturrock, RF (eds.): Human schistosomiasis. Wallingford, Oxon, UK, CAB International, 1993, pp. 237-270.

Damian RT, Rawlings CA, Bosshardt SC: The fecundity of Schistosoma mansoni in chronic nonhuman primate infections and after transplantation into naive hosts. J. Parasitol. 1986, 72, 741-745.

Duvall RH, DeWitt WB: An improved perfusion technique for recovering adult schistosomes from laboratory animals. Am. J. Trop. Med. Hyg. 1967, $16,483-486$.

Gönnert $R$, Andrews P: Praziquantel, a new broadspectrum antischistosomal agent. Z. Parasitenkd 1977, 52, 129-150.

James ER, Taylor MG: Transformation of cercariae to schistosomula: a quantitative comparison of transformation techniques and of infectivity by different injection routes of the organisms produced. J. Helminthol. 1976, 50, 223-233.

Johansen MV: Schistosoma bovis in goats. Host-parasite relationship during infection and following treatment with praziquantel. Ph.D. thesis, 1994, Copenhagen.

Johansen MV, Monrad J, Christensen NØ: Effects of praziquantel on experimental Schistosoma bovis infection in goats. Vet. Parasitol. 1996, 62, 83-91.

Kumar V, de Burbure G: Schistosomes of animals and man in Asia. Helminthological Abstracts (Series A), 1986, 55, 469-480.

Moloney NA, Webbe G: A rapid method for the infection of laboratory mice with Schistosoma japonicum. Trans. R. Soc. Trop. Med. Hyg. 1992, 76, 200-203.

Smithers SR, Terry RJ: The infection of laboratory hosts with cercariae of Schistosoma mansoni and the recovery of the adult worms. Parasitology $1965,55,695-700$.

Willingham $A L$, Johansen MV, Vennervald BJ, Christensen NØ, Nansen, $P$ : Experimental infection of
Danish Landrace/Yorkshire crossbred pigs with Schistosoma japonicum from the People's Republic of China. Acta Vet. Scand. 1994, 35, 395400.

Willingham $A L$, Hurst $M$ : The pig as a unique host model for Schistosoma japonicum infection. Parasitology Today 1996, 12, 132-134.

Willingham AL, Bøgh HO, Vennervald BJ, Johansen MV, Eriksen L, Christensen NØ, Nansen P: Worm establishment and egg production of Schistosoma japonicum in pigs infected by percutaneous methods or intramuscular injection. Vet. Parasitol. 1996, 61, 157-163.

Wilson RA, Coulson PS, Sturrock RF, Reid GD: Schistosome migration in primates: A study in the olive baboon (Papio anubis). Trans. R. Soc. Trop. Med. Hyg. 1990, 80, 80-83.

Yason CV, Novilla MN: Clinical and pathological features of experimental Schistosoma japonicum infections in pigs. Vet. Parasitol. 1984, 17, 47- 64.

\section{Sammendrag}

Kvantitativ bestemmelse af Schistosoma japonicum $i$ eksperimentelt inficerede grise ved perfusion af lever-og mesenterialvener.

En optimeret procedure til perfusion af den kinesiske blodikte, Schistosoma japonicum, ud af mesenterialvenerne hos grise beskrives. Metoden bygger på, at så meget som muligt af influx-væskens tryk kanaliseres igennem mesenterialvenerne. Derudover indgives et parasit-paralyserende ormemiddel (Praziquantel) oralt inden den egentlige perfusion. En plastik-slange indsættes i den decenderende aorta, blodkar til dele af kroppen, som ikke skal perfunderes, aflukkes med en pean, og en opsamlingsslange indsættes direkte i portal-venen. Ydermere tilsættes det kardilaterende stof, natriumnitroprussid, til perfusionsmediet, som er $40^{\circ} \mathrm{C}$ varmt. Effektiviteten af den optimerede metode blev testet i to forsøg. Perfusionstiden kunne reduceres betydeligt, idet ormene passivt blev skyllet til leveren efter ormebehandlingen. Derimod kunne en efterfølgende manuel undersøgelse af venerne omkring tarmen ikke undgås på trods af den optimerede procedure, idet der stadig fandtes enkelte såkaldte residualorm i de eksperimentelle grupper. Dette skyldtes i nogen grad, at en del af blodikterne sent $\mathrm{i}$ infektionsforløbet var lokaliseret $\mathrm{i}$ intravaskulære inflammatoriske reaktioner, som gjorde perfusion af dem umulig. 
(Received November 29, 1996; accepted January 28, 1997).

Reprints may be obtained from: H.O. Bøgh, Danish Centre for Experimental Parasitology, The Royal Veterinary and Agricultural University, Bülowsvej 13, DK-1870 Frederiksberg C, Denmark. E-mail: HOB@KVL.DK, tel: +4535282779, fax: +4535282774 . 
